\title{
Iman Perempuan Kanaan Berdasarkan Kitab Matius 15:21-28
}

\section{Canaanite Woman's Faith Based Matthew 15:21-28}

\author{
Anizah Chelsia ${ }^{1)^{*}}$ \\ Robi Panggarra ${ }^{2}{ }^{*}$ \\ 1) Mahasiswa Pascasarjana Sekolah Tinggi Filsafat Theologia Jaffray Makassar \\ *Penulis Korespondensi: anizahchelsiachen@gmail.com \\ 2) Dosen Sekolah Tinggi Filsafat Theologia Jaffray Makassar \\ *Penulis Korespondensi: robipanggarra@yahoo.com
}

Received: 2607 2020/ Accepted: 1512 2020/ Published: 16122020

\begin{abstract}
Abstrak
Tujuan penulisan artikel ini adalah: Pertama, untuk menjelaskan makna iman perempuan Kanaan berdasarkan Kitab Matius 15:21-28. Kedua, untuk memberikan suatu implikasi berdasarkan kajian tentang iman perempuan Kanaan bagi orang-orang percaya masa kini. Metode penelitian yang digunakan dalam penulisan artikel ini adalah metode Hermeneutik Eksegesis kualitatif terkait genre dari Kitab Matius 15:21-28. Dari hasil penelitian ini penulis menarik kesimpulan: Pertama, iman yang sejati hanya bergantung pada belas kasihan Yesus. Iman yang sungguh-sungguh kepada Yesus adalah iman yang hanya bergantung pada belas kasihan dari Yesus. Kedua, iman yang benar adalah iman yang tidak mudah menyerah. Sebagai orang percaya harus tetap bertahan apapun persoalan yang akan terjadi pada kehidupan setiap orang. Ketiga, tetap bersabar menunggu waktu Tuhan dan lebih mengutamakan apa yang menjadi tujuan Allah bagi umatNya. Keempat, tetap mempertahankan iman percaya kepada Tuhan dan terus berserah kepada Tuhan yang adalah Anak Daud.
\end{abstract}

Kata-kata Kunci: Iman, Matius 15:21-28, Perbuatan, Perempuan Kanaan, Yesus.

\begin{abstract}
The purpose of this article is: First, to explain the meaning of the faith of Canaanite women based on the Book of Matthew 15: 21-28. Second, to provide implications for the assessment of the faith of Canaanite women for those who believe in the future. The research method used in this research journal is the Hermeneutic Exegesis qualitative method which is related to the genre of the Book of Matthew 15:21-28. From the results of this study, the authors draw conclusions: First, true faith depends only on the grace of Jesus. A truly
\end{abstract}


extraordinary faith for Jesus is a faith that depends only on Jesus' mercy. Second, true faith is faith that does not give up easily. As believers must be persistent whatever will happen in everyone's life. Third, remain patient waiting for God's time and prioritize what God's purpose for His people. Fourth, continue to believe in God and continue to surrender to God who is the Son of David.

Keywords: Acts, Faith, Canaanite Woman, Matthew 15:21-28, Jesus.

\section{PENDAHULUAN}

Iman adalah hal yang penting bagi kehidupan orang Kristen. Iman juga merupakan kebutuhan dasar bagi kehidupan orang Kristen, sebab hanya dengan iman orang percaya dapat melakukan maupun menjalankan kehidupan ini sebagai orang Kristen. Orang yang percaya hidup dalam iman. Iman yang benar adalah iman yang percaya kepada Yesus Kristus.

Beriman kepada Allah adalah orang-orang yang percaya kepada Allah, yang mengandalkan dan yakin kepada Allah. Kepercayaan yang menyelamatkan juga mengikut sertakan emosi dan keinginan orang-orang percaya kepada Allah, yang berarti memerlukan pengetahuan apa yang telah Allah lakukan bagi setiap orang percaya dalam Kristus, dan mendapatkan sukacita terhadap keselamatan dan janji yang teguh untuk mempercayakan kepada Allah mengenai semua yang terjadi di dalam kehidupan setiap orang percaya (Berends, 2010, p. 242).

Meskipun dalam kehidupan orang-orang percaya banyak mengalami masalah ataupun pergumulan, dan setiap orang percaya pasti memiliki keyakinan iman kepada Kristus, dan setiap masalah dan pergumulan itu pasti Yesus akan memberikan jalan keluar dan tidak ada yang mustahil bagi orang yang percaya.

Dalam Kitab Matius 17:20b mengatakan: "Sebab Aku berkata kepadamu: Sesungguhnya sekiranya kamu mempunyai iman sebesar biji sesawi saja kamu dapat berkata kepada gunung ini: Pindah dari tempat ini ke sana, - maka gunung ini akan pindah, dan takkan ada yang mustahil bagimu." Artinya setiap orang percaya ketika melakukan sesuatu yang sebelumnya tidak terpikirkan akan bisa terjadi, ketika memiliki iman pasti akan terjadi sesuai dengan apa yang diinginkan. Iman adalah dasar dari segala sesuatu yang kita harapkan dan bukti dari segala sesuatu yang tidak kita lihat (Ibr. 11:1).

Dalam Alkitab terdapat narasi yang ada kaitannya dengan iman seseorang, yaitu dalam Kitab Matius 15:21-28 yang menceritakan sebuah kisah menarik mengenai perempuan Kanaan yang datang kepada Yesus untuk meminta pertolongan untuk menyembuhkan anaknya yang mengalami kerasukan setan. Jika dilihat dari latar belakang perempuan Kanaan ini, bangsa Kanaan merupakan salah satu dari sekian banyak bangsa yang hendak dimusnahkan Allah melalui bangsa Israel. Allah berjanji 
untuk membawa bangsa Israel ke tanah Perjanjian, yaitu tanah Kanaan dan untuk itu bangsa Israel harus menaklukkan orang-orang Kanaan yang menempati tanah itu. Selain itu, ada alasan di balik perintah Allah untuk memusnahkan bangsa Kanaan yang berhubungan dengan kebudayaan dan agama Kanaan (Rouw, 2017, p. 202).

Dengan demikian, dari kebudayaan dan agama yang mereka miliki bangsa Kanaan adalah bangsa yang sangat berdosa bagi Allah, mereka tidak hanya melakukan hal-hal yang sangat dibenci Allah, tetapi juga mencoba menjerat orang Israel untuk mengikuti kebiasaan agama mereka. Jadi, memang patut bangsa Kanaan memperoleh hukuman dari Allah. Kehidupan mereka yang penuh dengan berbagai penyimpangan membuat mereka menjadi bangsa yang bejat dan tidak layak untuk Allah sehingga pantas untuk dimusnahkan (Lasor, Hubbard, dan Bush, 1993, p. 292).

Dengan demikian semua orang tidak ada yang layak untuk disembuhkan karena terlalu berdosa, sama seperti perempuan Kanaan ini yang juga tidak layak mendapatkan kesembuhan untuk anaknya yang sedang mengalami kerasukan setan. Dalam Matius 15:22 perempuan Kanaan ini mengatakan "Kasihanilah aku, ya Tuhan, Anak Daud, karena anakku perempuan kerasukan setan dan sangat menderita. Ini adalah permohonan dari perempuan Kanaan ini kepada Yesus.

Namun, narasi ini menarik karena Yesus menunjukkan respons yang tidak biasa ketika bertemu dengan perempuan Kanaan. Matius menuliskan bahwa Yesus sama sekali tidak memberi jawaban terhadap pemintaan perempuan tersebut. Matthew Henry menjelaskan sikap dengan sikap Yesus menyatakan, bahwa:

Selama ini telinga-Nya selalu terbuka dan selalu memperhatikan seruan-seruan orang yang memohon kepada-Nya, dan bibir-Nya, yang berbicara manis seperti madu selalu siap memberikan jawaban damai sejahtera. Namun, kepada wanita yang malang ini. la sama sekali menutup telinga-Nya; dan kendati wanita itu memohon, dia tidak memperoleh derma dan jawaban apa-apa. Sungguh mengherankan mengapa wanita itu tidak langsung pergi saja sambil marahmarah dan berkata: Inikah Dia yang begitu terkenal akan belas kasihan dan kelembutan-Nya itu? Benarkah perkataan orang bahwa sudah ada begitu banyak orang yang permohonannya didengar dan dijawab oleh-Nya? (Henry, 2008, p. 748)

Dalam Tafsiran Wycliffe juga dijelaskan, tetapi Yesus tidak menjawab. Sebagian disebabkan oleh usaha Yesus untuk tetap menyendiri (Pfeiffer dan Harison, 2013, p. 96). Sama sekali tidak menanggapi, suatu hal yang sangat tidak lazim, Yesus umumnya merespons setiap permintaan tolong dan terkadang bahkan berinisiatif sebelum orang yang bersangkutan sempat meminta. Matius menekankan sikap diam Yesus ini dengan berkata ia sama sekali tidak menjawab mengapa Yesus mengambil sikap ini. Para murid tampaknya memahami alasannya: wanita orang Kanaan, bukan orang Yahudi dan bagi mereka, tangisannya tidak lebih sekedar gangguan (Morris, 2016, p. 412). Ketika perempuan itu memohon meminta pertolongan, di ayat 23 Yesus sama sekali tidak menjawab perempuan itu dan disaat itu juga terdapat murid- 
murid-Nya yang meminta untuk perempuan itu diusir. Mereka berkata: "Suruhlah ia pergi, ia mengikuti kita dengan berteriak-teriak". Memberikan perhatian kepada doadoa orang-oranng saleh itu baik, dan harus berkeinginan untuk memiliki perhatian seperti itu. Tetapi murid-murid, walaupun berharap agar wanita itu bisa memperoleh apa yang dia inginkan, mereka malah lebih memikirkan kenyamanan mereka sendiri daripada kepuasan wanita yang malang itu (Morris, 2016, p. 749). Sungguh menjadi suatu penolakan yang ironis.

Dalam teks ini, terjadi perdebatan Yesus dengan perempuan Kanaan tersebut tentang selayak apakah yang harus perempuan Kanaan itu miliki agar ia menerima mukjizat dari Yesus. Sebab Yesus mengatakan pada ayat ke 24 "Aku diutus hanya kepada domba-domba yang hilang dari umat Israel" yang artinya Yesus datang hanya untuk Israel, di luar dari bangsa itu Yesus tidak memiliki misi. "Misi Yesus di bumi ini ditujukan bagi Israel, yang di sini dilukiskan sebagai domba yang hilang" (Morris, 2016, p. 413).

B. F. Drewes mengatakan, “Domba-domba yang hilang dari umat Israel pertama-tama menunjuk kepada orang banyak, yang Lelah dan terlantar seperti domba yang tidak bergembala. Perkataan Yesus ini senada dengan apa yang dibaca di ayat 24; kepada perempuan yang dari umat Israel (seorang perempuan Kanaan) yang mencari keselamatan bagi anaknya pada Yesus (Drewes, 1982, p. 235). Jadi, Yesus hanya datang untuk orang Israel.

Bangsa Israel dilihat sebagai umat Allah. Yesus sedang berkata misi-Nya adalah kepada umat Allah Perjanjian Lama, dan Injil dengan cukup jelas menunjukkan kepada orang-orang bahwa seperti inilah cara Yesus bekerja. la sangat jarang memiliki relasi dengan orang-orang non-Yahudi, dan para murid-Nya juga diutus hanya kepada orang Israel (10:5-6; Morris, 2016, p. 413). Yesus datang hanya untuk orang-orang Israel itu, dan perempuan yang datang menghampiri Yesus pada saat itu adalah termasuk orang yang bukan Israel, perempuan itu adalah orang Kanaan. Orang-orang Kanaan asli adalah penyembah-penyembah banyak dewa-dewi. Dewa yang tertinggi adalah EL, yang dipercayai sebagai pencipta alam semesta dan sekaligus kepala dari semua dewa (Wismoady, 2009, p. 117). Kanaan adalah bangsa yang dikutuk, sebab di dalam Kejadian. 9:25 mengatakan terkutuklah Kanaan, hendaklah menjadi hamba-hamba yang paling hina bagi saudara-saudaranya.

Sedangkan, Yesus sendiri adalah orang Yahudi, dan penulis melihat bahwa Yahudi dan non Yahudi tidak bisa bersahabat, karena orang non-Yahudi adalah orang-orang yang terkutuk dan juga bisa dibilang najis. Yesus diutus oleh Bapa di sorga untuk tujuan yang spesifik, yaitu menuntaskan misi-Nya yaitu menyelamatkan bangsa Israel (Morris, 2016, p. 412-13). Tetapi pada ayat ke 28 Yesus menjawab dan berkata: "Hai ibu, besar Imanmu, maka jadilah kepadamu seperti yang kaukehendaki." Seketika itu juga anak dari perempuan Kanaan itu sembuh. Mengapa Yesus pada akhirnya mengabulkan permintaan perempuan Kanaan ini, walaupun Yesus sudah mengatakan kalau Yesus hanya diutus hanya kepada orang Israel? Jika, hal itu dikaitkan dengan iman perempuan Kanaan itu, mengapa demikian? Apa arti iman 
perempuan Kanaan ini? Apakah tindakan Yesus hanya bergantung pada iman perempuan itu? Dan iman perempuan itu berdasarkan apa? Dan iman seperti apakah yang miliki oleh perempuan ini?

\section{METODE}

Adapun metode yang digunakan oleh penulis adalah metode penelitian kualitatif melalui Library Research atau penelitian perpustakaan, yaitu membaca buku-buku, menyelidiki kitab yang berkaitan dengan pokok bahasan artikel ini.

Metode penelitian yang digunakan oleh penulis dalam penulisan artikel juga ini adalah metode penulisan Hermeneutik Eksegesis. Kamus Webster mendefinisikan hermeneutik sebagai "ilmu menafsir, atau ilmu menemukan arti dari perkataan atau frasa seorang penulis, lalu menjelaskannya kepada orang-orang lain; eksegesis; terutama berlaku untuk penafsiran ayat-ayat Kitab Suci" (Conner, 2004, p. 1). Hermeneutik bukan saja merupakan ilmu pengetahuan tetapi juga sebagai seni yang melibatkan diri penafsir dengan tujuan mencari maksud yang ingin disampaikan oleh penulis Alkitab (Sutanto, 1998, p. 3). Jadi, inti dari hermeneutik itu adalah berpusat kepada penafsiran, yang dimulai dengan eksegesis. Gordon D. Fee \& Douglas Stuart dalam bukunya Hermeneutik Bagaimana Menafsirkan Firman Tuhan dengan Tepat menuliskan:

Eksegesis adalah hal mempelajari Alkitab secara sistematis dan teliti untuk menemukan arti asli yang dimaksudkan. Pada dasarnya hal ini adalah suatu tugas yang berkenan dengan sejarah. Suatu usaha untuk mendengar Firman sebagaimana penerima yang mula-mula mendengarkannya, untuk menemukan apa yang dimaksudkan mula-mula oleh perkataan Alkitab itu. (Fee dan Stuart, 1989, p. 8)

Prinsip hermeneutik yang dikerjakan penulis adalah pertama dengan menentukan latar belakang konteks nas baik konteks sebelum dan sesudah nas. Menentukan genre nas. Kemudian menguraikan struktur nas dan menganalisis teks tersebut berdasarkan bahasa asli.

\section{HASIL DAN PEMBAHASAN}

\section{Perempuan Datang Pada Yesus dan Meminta Dikasihani (ay. 21-22)}

Pada ayat 21 mengatakan Lalu Yesus pergi dari situ dan "menyingkir" dalam

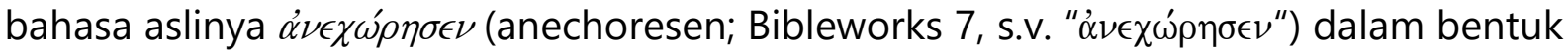
kata kerja Aorist (untuk menyatakan bahwa suatu hal pernah terjadi atau pernah dilakukan \{lampau selesai\}; Suawa, 2009, p. 35) Indikatif aktif (Indikatif berarti menyajikan tindakan sebagai suatu kepastian atau menunjukkan suatu tindakan yang benar-benar terjadi; Suawa, 2009, p. 36) orang pertama tunggal yang berarti Yesus sedang menyingkir ke daerah Tirus dan Sidon. Sehabis Yesus dan murid-murid-Nya 
telah selesai mendatangi orang-orang yang selalu mengutamakan adat istiadatnya orang-orang itu, sehingga orang-orang itu melanggar peraturan yang telah Yesus berikan kepada orang-orang itu. Yesus langsung menyingkir dari daerah itu untuk menuju ke daerah yang membutuhkan mujizat dari Yesus. Setelah Yesus dan muridmurid-Nya tiba di daerah itu yaitu daerah Tirus dan Sidon, datanglah dalam bahasa

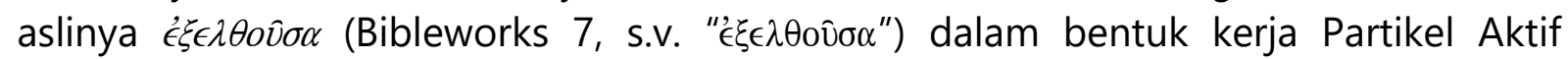
Nominatif Feminim Singular (Nominatif berarti menunjukkan fungsinya sebagai 'subjek/pelaku' kalimat; Suawa, 2009, p. 31), yang di mana seorang perempuan Kanaan dari daerah itu dan berseru: "Kasihanilah aku, ya Tuhan, Anak Daud", karena anakku perempuan kerasukan setan dan sangat menderita ayat 22, kalimat yang menunjukkan suatu tindakan yang benar-benar terjadi. Kata tersebut dalam Terjemahan aslinya é $\lambda \epsilon ́ \eta \sigma o ́ \nu ~ \mu \epsilon ~ \kappa u ́ p \iota \epsilon$ viós $\Delta \alpha v i ́ \delta$ (elleson me Kyrie huios David). Dalam Terjemahan Lama (TL) "Ya Tuhan, ya Anak Daud, kasihankanlah hamba". Dalam terjemahan Indonesia Literal Translation (ILT) "Tuhan, Anak Daud, berilah aku kemurahan". Menurut Firman Allah Yang Hidup (FAYH) "Kasihanilah saya, ya Tuhan, Anak Raja Daud". Menurut King James Version (KJV) "Have mercy on me, O lord, thou Son of David" (kasihanilah aku, ya Tuhan, Engkau Anak Daud.

Kata "Kasihanilah" dalam bahasa Yunaninya adalah " $\epsilon \lambda \epsilon \sigma^{\prime \prime}$ (eleos; Newman Jr., 1991, p. 53) kata kerja Aoris Imperatif aktif (Imperatif berarti menyampaikan permintaan dan bukan perintah langsung; Suawa, 2009, p. 194) orang ke dua tunggal yang berarti belas kasihan (Sutanto, 2003, p. 268). Perempuan ini meminta belaskasihan kepada Yesus untuk kesembuhan anaknya. Dapat dilihat bahwa perempuan ini dengan kesungguhan hatinya meminta belaskasihan kepada Yesus agar anaknya dapat sembuh dari kerasukan setan.

Menurut Kamus Besar Bahasa Indonesia kata "Kasihanilah" atau dapat diperkecil lagi yaitu dengan sebutan "Kasihan" berarti seruan menyatakan rasa belas (Depdiknas, 2001, s.v. "kasihan"). Yang artinya perempuan ini dengan kesungguhan hatinya meminta pertolongan kepada Yesus, dan dia sangat mengharapkan Yesus akan membantu dirinya. Anak perempuan ini sangat menderita kata menderita atau derita dalam Kamus Besar Bahasa Indonesia adalah sesuatu yang menyusahkan yang ditanggung di hati (seperti kesengsaraan, penyakit; Depdiknas, 2001, s.v. "derita"). Jadi anak dari perempuan ini sangat-sangatlah menderita sehingga membuat dirinya sangat sengsara.

"Belas kasihan kepada anak-anak adalah juga belas kasihan kepada orang tua. Kebaikan yang diperlihatkan kepada milik orang itu adalah juga kebaikan kepada orang itu, dan orang tersebut harus memandangnya demikian. Perhatikanlah, orangtua wajib berdoa bagi anak-anak mereka dengan sungguh-sungguh, terutama bagi jiwa mereka" (Henry, 2008, p. 746-47). Dan orangtua sangatlah menyayangi anak-anak mereka ketika mereka mengalami yang namanya penderitaan. Sehingga anak adalah fokus utama orangtua dari apapun.

Perempuan ini bukan sekedar meminta belaskasihan kepada Yesus, tetapi dia sangat bersungguh-sungguh mengharapkan kesembuhan anaknya dari Yesus. Di sini 
dapat dilihat bersama bahwa perempuan ini meminta Yesus untuk menyembuhkan anaknya dan mengatakan bahwa Yesus adalah Anak Daud, berarti perempuan ini sangat bersungguh-sungguh dari dalam hatinya untuk mengharapkan uluran tangan Tuhan, untuk kesembuhan anaknya. "Perempuan ini mengakui Yesus sebagai Mesias, dan inilah hal terbesar yang harus dipegang oleh iman. Iman perlu pengakuan ini supaya mendapat penghiburan. Dari Tuhan kita bisa mengharapkan perbuatanperbuatan yang penuh kuasa, sebab la dapat memerintahkan kelepasan bagi kita. Dari Anak Daud kita bisa mengharapkan segala belas kasihan dan anugerah yang telah dinubuatkan tentang Dia" (Henry, 2008, p. 746). Meskipun perempuan ini bukanlah orang Yahudi, namun dia sangat menghormati Tuhan dan dia percaya kepada Tuhan atas kesembuhan anaknya.

Dari pembahasan di atas dapat disimpulkan bahwa ketika seseorang datang kepada Yesus untuk meminta pertolongan dia harus memiliki hati yang bersungguhsungguh berharap sesuatu mujizat akan terjadi didalam kehidupannya.

\section{Respons Yesus dan Murid-Murid-Nya (ay. 23-27)}

\section{Yesus Tidak Menjawab (ay. 23a)}

Pada ayatnya yang ke-23a mengatakan "Tetapi Yesus sama sekali tidak

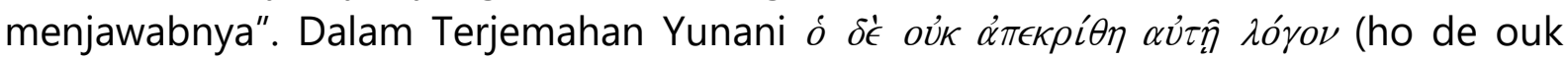
apekrithe aute logon) Menurut Terjemahan Lama (TL) "Tetapi sepatah kata pun tidak dijawab oleh Yesus kepada perempuan itu." Menurut terjemahan Indonesia Literal Translation (ILT) "Namun, Dia tidak menjawab sepatah kata pun kepadanya." Menurut terjemahan Firman Allah Yang Hidup (FAYH) "Tetapi Yesus sama sekali tidak menyahut." Menurut terjemahan King James Version (KJV) "But he answered her not a word Tapi Dia tidak menjawab sepatah kata pun padanya. Jadi dari semua terjemahan tersebut yang sesuai dengan Bahasa aslinya adalah terjemahan dari King James Version "But he answered her not a word" yang di mana Yesus tidak menjawab

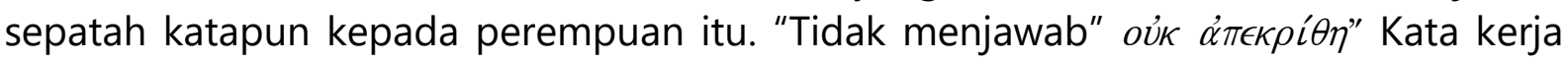
aoris Indikatif (indikatif berarti menyajikan tindakan sebagai suatu kepastian atau menunjukkan suatu tindakan yang benar-benar terjadi; Suawa, 2009, p. 36) pasif orang ketiga tunggal, yang di mana Yesus tidak menjawab seruan dari perempuan Kanaan ini, sedangkan perempuan ini sudah bersungguh-sungguh datang untuk bertemu dengan Yesus untuk meminta pertolongan kepada Yesus. Betapa besar kesungguhan hati perempuan ini untuk meminta pertolongan kepada Yesus demi kesembuhan anaknya, namun Yesus tidak memberikan balasan kepada perempuan ini malah sebaliknya Yesus hanya berdiam dan tidak menjawab ketika perempuan ini meminta pertolongan kepada Yesus.

Dapat dilihat bahwa kesungguhan hati yang dimiliki oleh Perempuan Kanaan ini sangatlah besar, dia tidak menyerah begitu saja meskipun doanya tidak dijawab oleh Yesus. Dengan demikian, dari pembahasan di atas dapat disimpulkan bahwa orangorang percaya harus memiliki kesungguhan hati seperti yang dimiliki oleh Perempuan 
Kanaan ini yang tidak mudah menyerah begitu saja ketika doa tidak dijawab oleh Yesus.

\section{Murid Meminta Perempuan Kanaan Disuruh Pergi (ay. 23b)}

Ketika Yesus tidak menjawab permintaan perempuan ini, murid-murid-Nya datang dan meminta kepada-Nya: "Suruhlah ia pergi, ia mengikuti kita dengan berteriak-teriak." Disini murid-murid Yesus menyuruh Yesus untuk mengusir perempuan ini yang sudah mengganggu mereka ketika mereka berjalan untuk melakukan pelayanan atau melakukan mujizat. Kata suruhlah ia pergi, ia mengikuti

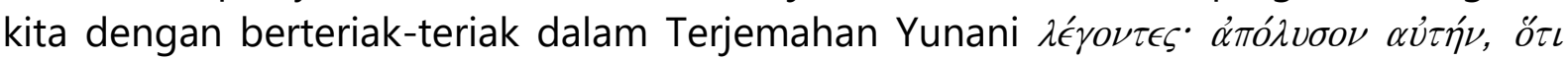
$\kappa \rho \alpha ́ \zeta \epsilon \iota$ ŏ $\iota \iota \sigma \theta \epsilon \nu \dot{\eta} \mu \hat{\omega} \nu$ (legontes apolyson auten hoti krazei opisthen hemon; Bibleworks 7). Terjemahan Lama (TL) "Suruhlah perempuan itu pergi, karena ia berteriak-teriak di belakang kita". Menurut terjemahan Indonesia Literal Translation (ILT) "Suruhlah dia pergi, sebab ia berteriak-teriak di belakang kita". Menurut terjemahan Firman Allah Yang Hidup (FAYH) "Suruhlah perempuan itu pergi, kata mereka, karena dia terus mengganggu dengan permohonannya itu." Menurut terjemahan King James Version (KJV) Saying, send her away, for she crieth after us. Dari semua terjemahan, terjemahan yang sesuai adalah terjemahan FAYH "Suruhlah perempuan itu pergi, kata mereka, karena dia terus mengganggu dengan permohonannya itu."

Murid-murid Yesus ini meminta agar perempuan ini diusir dari hadapan mereka, karena perempuan ini sudah mengganggu mereka dan merusak suasana mereka pada saat itu, dan juga perempuan ini dianggap najis karena dia adalah orang bukan Yahudi, sehingga membuat mereka ada yang marah ketika perempuan ini datang kepada mereka. murid-murid Yesus ini ingin perempuan itu pergi dari hadapan mereka, hanya karena perempuan ini mengganggu karena teriakan permintaan perempuan ini.

Kata "suruh" dalam Kamus Besar Bahasa Indonesia perintah (supaya melakukan sesuatu; Depdiknas, 2001, s.v. "suruh"). Sedangkan Suruh dalam bahasa aslinya adalah $\lambda \epsilon ́ \gamma o \nu \tau \epsilon \varsigma$ kata kerja present (present: untuk menunjukan bahwa suatu pekerjaan sedang dilakukan atau dilakukan berulang kali (terus menerus) dalam waktu kini atau dikemudian hari pasti terjadi; Suawa, 2009, p. 35) partikel aktif nominatif maskulin jamak. Jadi murid-murid Yesus menyuruh untuk Perempuan Kanaan itu pergi dari situ. Kemudian, kata "mengganggu" dalam Kamus Besar Bahasa Indonesia memiliki lima arti yang berbeda: (i). Menggoda; mengusik, (ii). Merintangi, menyebabkan tidak berjalan sebagaimana mestinya (tentang keadaan umum, kesehatan badan, dan sebagainya); (iii). Merisaukan (tentang hati, pikiran); (iv). Merusak suasana; (v). Mendatangkan kekacauan (kerusuhan dan sebagainya; Depdiknas, 2001, s.v. "mengganggu")." Jika kembali pada nas, kata "Mengganggu" adalah sesuatu hal yang tidak baik, yang membuat segala sesuatu tidak dapat berjalan sesuai dengan yang diinginkan ataupun sesuatu yang menyebabkan sesuatu menjadi rusak.

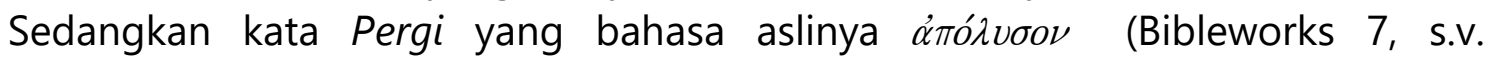

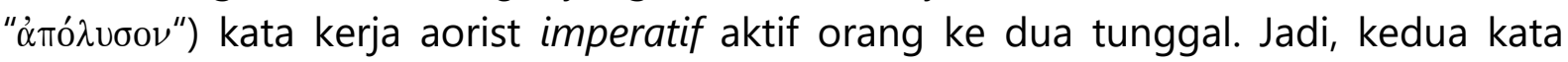


tersebut di simpulkan bahwa murid menginginkan agar Yesus menyuruh untuk Perempuan Kanaan itu di suruh dari hadapan orang-orang itu. Jadi, dari pengertian di atas bahwa Perempuan Kanaan ini datang hanya untuk mengganggu Yesus dan murid-murid-Nya. Namun Perempuan Kanaan ini tidak memperdulikan itu, malah Perempuan Kanaan ini tetap bertahan dengan kehendak dan keyakinan yang dimilikinya, yaitu meminta pertolongan kepada Yesus untuk kesembuhan anaknya yang kerasukan setan.

\section{Yesus Diutus Kepada Domba-domba Yang Hilang (ay. 24)}

Kemudian pada ayat ke 24 Yesus mengatakan kepada perempuan ini "Aku diiutus hanya kepada domba-domba yang hilang dari umat Israel". Menurut

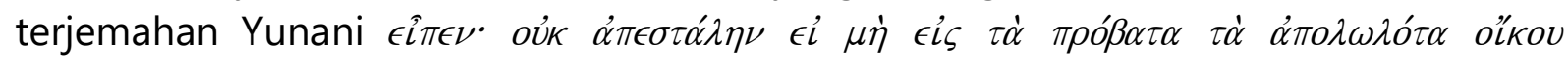

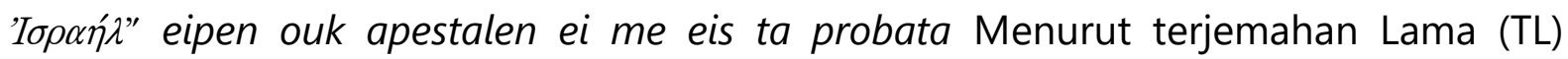
"Tiadalah Aku disuruhkan kepada orang lain hanya kepada segala domba yang sesat dari antara bani Israel", sedangkan terjemahan Indonesia Literal Translation (ILT) "Aku tidak diutus kecuali kepada domba-domba yang hilang dari keluarga Israel". Menurut terjemahan Firman Allah Yang Hidup (FAYH) "Aku diutus untuk menolong bangsa Yahudi, yaitu domba-domba Israel yang hilang-bukan bangsa yang lain". Menurut terjemahan King James Version (KJV) "I am not sent but unto the lost sheep of the house of Israel". Dari semua terjemahan di atas, yang sesuai dengan teks tersebut adalah terjemahan dari (FAYH) "Aku diutus untuk menolong bangsa Yahudi, yaitu domba-domba Israel yang hilang-bukan bangsa yang lain". Dari perkataan Tuhan ini sudah menjawab bahwa Yesus hanya datang kepada orang-orang Israel, diluar dari orang Israel Tuhan tidak akan menjawab ataupun Tuhan tidak ada tanggung-jawab untuk melakukan mujizat bagi mereka orang diluar Israel.

Kata diutus menurut bahasa aslinya adalah $\alpha \pi \epsilon \sigma \tau \alpha ́ \lambda \eta \nu$ (apostello; Biblework 7,

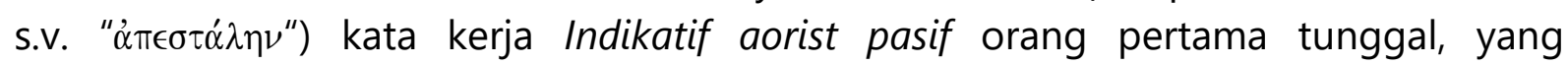
menunjukkan suatu bentuk lampau, di mana perkataan yang Yesus katakan pada saat itu tetap berdampak hingga saat ini. Sedangkan kata hanya dalam bahasa aslinya

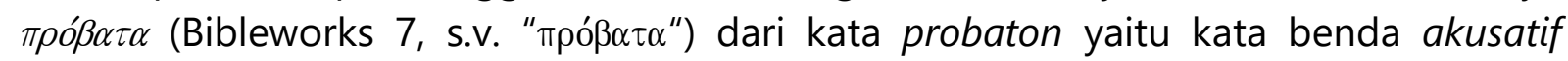
(akusatif disebut sebagai kasus "pembatasan", artinya, memberi batas akhir pada suatu tindakan; Suawa, 2009, p. 32) neuter jamak, yang menujukkan suatu batas pada suatu tindakan, dimana perkataan yang Yesus katakan pada itu terbatas hanya disitu saja.

Dengan demikian pengertian di atas mengatakan bahwa Yesus hanya diutus bagi domba-domba yang hilang dari umat Israel. Yesus mengatakan seperti itu karena perempuan itu bukanlah orang Yahudi dan dia adalah orang yang najis karena pada saat itu ada murid-murid Yesus yang tidak suka perempuan itu berada dekat mereka karena dia najis.

Dan juga alasan Yesus mengatakan bahwa Dia hanya diutus kepada dombadomba yang hilang dari umat Israel, untuk memberitahukan kepada perempuan itu karena dia tidak layak untuk mendapatkan mujizat, karena tidak seorangpun yang 
layak disembuhkan karena terlalu berdosa, termasuk anak dari perempuan Kanaan ini. Jadi, mereka dapat disembuhkan oleh karena kasih karunia Tuhan, oleh karena belas kasihan Tuhan. Dan ada rencana Yesus dibalik itu semua yaitu Yesus ingin melihat kesungguhan hati dari perempuan itu, dan di situ ada murid-murid Yesus yang tidak suka dengan orang non-Yahudi. Jadi, Yesus datang bukan hanya untuk orang Yahudi saja, tetapi untuk orang lain juga, karena ini dibuktikan dengan perumpamaan tentang penggarap-penggarap kebun anggur, yang memberikan perumpamaan orang yang membunuh anak di dalam kebun itu dan Yesus mengatakan "Kerajaan Allah akan diambil dari padamu dan akan diberikan kepada suatu bangsa yang akan menghasilakan buah Kerajaan itu (Matius 21:43)." Jadi, benar perkataan yang dikatakan oleh Yesus bahwa Dia datang untuk bangsa Israel, tetapi ini dari segi sejarah urutan keselamatan. Jadi, Yesus datang untuk urus Israel, tetapi dengan rencananya untuk menjangkau semua bangsa. Jadi, Yesus membuat mujizat itu di depan murid-murid-Nya. Namun pada akhirnya Yesus pun menyembuhkan anaknya yang mengalami kerasukan setan, karena perempuan itu percaya bahwa Yesus akan menolongnya, sehingga membuat dia tetap berada diposisi itu, meskipun pada awalnya Yesus mengatakan bahwa Dia hanya diutus kepada domba-domba yang hilang dari umat Israel.

\section{Perempuan Mendekat Untuk Menyembah dan Minta Ditolong (ay. 25)}

Pada ayat sebelumnya Perempuan Kanaan ini ditolak ditolong oleh Yesus, namun pada ayat 25 ini dikatakan bahwa Perempuan ini mendekat dan menyembah kepada Yesus sambil berkata: "Tuhan, tolonglah aku." Dalam Bahasa asli (Yunani)

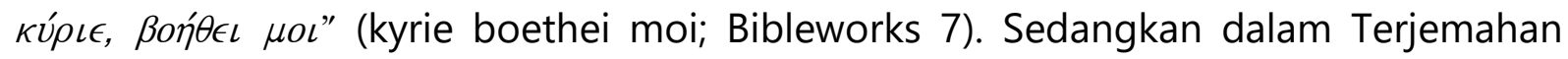
Lama (TL) "Ya Tuhan, tolonglah hamba!". Menurut terjemahan Indonesia Literal Translation (ILT) "Tuhan, tolonglah aku". Menurut terjemahan Firman Allah Yang Hidup (FAYH) "Tuhan, tolonglah saya". Terjemahan King James Version (KJV) "Lord, help $m e^{\prime \prime}$. Dari semua terjemahan yang sesuai adalah terjemahan Indonesia Literal Translation. Tuhan tolonglah aku, kata tolong dalam bahasa aslinya adalah $\beta$ jó $\theta \epsilon \iota$ (Bibleworks 7, s.v. "ßon $\theta \in \iota^{\prime \prime}$ ) kata kerja imperatif present aktif orang kedua tunggal, yang menunjukkan harapan dari seorang Perempuan untuk menerima bantuan dari Yesus. Itu adalah kalimat yang Perempuan Kanaan itu ucapkan kepada Yesus, meskipun dia ditolak oleh Yesus dan tidak dianggap, namun dia tetap mendekat dan menyembah Yesus.

Kata "mendekat" menurut Kamus Besar Bahasa Indonesia adalah datang menghampiri (Depdiknas, 2001, s.v. "mendekat"). Menurut kata asli (Yunani) '́ $\lambda \theta 0 \hat{\sigma \alpha}$ (erchomai; Bibleworks 7, s.v. "' $\lambda \theta \theta 0 \hat{\sigma \alpha} \alpha$ ") yang artinya: mendekat, menghampiri memiliki bentuk kata kerja partisip aorist aktif nominatif feminim tunggal. Yang artinya Perempuan ini mendekatkan diri kepada Yesus untuk meminta pertolongan kepada Yesus. Kemudian kata "Menyembah" menurut Kamus Besar Bahasa Indonesia ada tiga arti yang berbeda, antara lain: (i). Menghormati dengan mengangkat sembah; (ii). Memuja (sesuatu sebagai Tuhan atau dewa; (iii). Mengaku di bawah perintah; takluk 


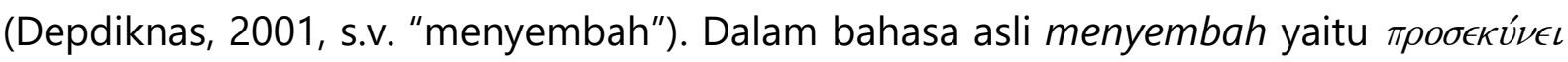
(Bibleworks 7, s.v. "пробєкúvєเ") kata kerja indikatif imperfek aktif orang ketiga tunggal Jika kembali ke nas menyembah adalah sesuatu yang dilakukan untuk berdoa, bermohon kepada Sang Pencipta. Menyembah dengan kesungguhan hati kita. Jadi kedua kata itu digabungkan menjadi sesuatu yang khusyuk yaitu mendekatkan diri kepada Yesus dan menyembah dengan kerendahan hati dan kesungguhan hati.

Dengan demikian, dari pembahasan di atas dapat simpulkan bahwa perempuan ini mendekat diri dan menyembah kepada Yesus, untuk kesembuhan anaknya yang sedang mengalami kerasukan setan, dan perempuan ini menyembah dengan sungguh-sungguh dengan penuh kepercayaan dan sambil berkata: Tuhan, tolonglah aku, itulah bukti bahwa Perempuan ini sangat mengharapkan kesembuhan anaknya. Walaupun Perempuan ini diabaikan dan tidak dipedulikan, namun dia tetap teguh dengan Iman yang dimilikinya.

\section{Roti Untuk Orang Yahudi Tidak Untuk Orang Non-Yahudi (ay. 26)}

Dan setelah perempuan ini mendekatkan dirinya kepada Yesus dan menyembah-Nya, namun Yesus menjawab: "Tidak patut mengambil roti yang disediakan bagi anak-anak dan melemparkannya kepada anjing." Dalam terjemahan

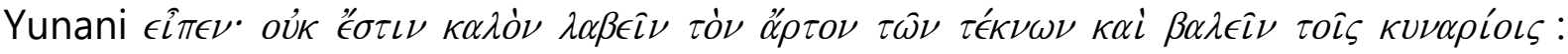
eipen ouk estin kalon labein ton arton ton teknon kai balein tois kynarrios. Dalam terjemahan Lama (TL) "Tiada patut diambil roti dari anak-anak, lalu mencampakkan kepada anjing". Terjemahan Indonesia Literal Translation (ILT) "Tidaklah baik mengambil roti anak-anak dan melemparkannya kepada anjing". Terjemahan Firman Allah Yang Hidup (FAYH) "Rasanya tidak patut mengambil roti dari anak-anak dan melemparkannya kepada anjing". Terjemahan King James Version "It is not meet to take the children's bread, and to cast it to dogs". Dari semua terjemahan di atas yang sesuai adalah terjemahan Indonesia Literal Translation "Tidaklah baik mengambil roti anak-anak dan melemparkannya kepada anjing", kalimat itu adalah yang Tuhan Yesus katakan kepada Perempuan Kanaan itu.

Kata tidak patut yaitu tidak layak, tidak pantas, tidak senonoh, dan masih banyak lagi. Itu adalah kata yang Yesus katakan kepada Perempuan Kanaan itu yang di mana tidak patut mengambil roti kepada anak-anak. Sedangkan, kata "Melempar" dalam Kamus Besar Bahasa Indonesia ada dua arti: (i). Membuang jauh-jauh; (2). Melontari (dengan; Depdiknas, 2001, s.v. "melempar")." Melempar dalam bahasa aslinya adalah $\beta \alpha \lambda \epsilon \hat{\imath} \nu$ (Bibleworks 7, s.v. " $\beta \alpha \lambda \epsilon \hat{\imath} \nu$ ") kata kerja infinitive (Infinitif: kata yang tidak memiliki signifikansi waktu apapun; Mounce, 2011, 247) aorist aktif, yang menunjukkan sesuatu yang pernah dilakukan tetapi tidak menyebutkan kata waktu. Jika kembali ke nas melempar yang berarti membuang sesuatu dan itu pernah dilakukan. Begitu juga yang dikatakan oleh Yesus kepada perempuan Kanaan ini yaitu melemparkan. Jika kedua kata itu disatukan bahwa perempuan itu tidak Patut mengambil roti yang disediakan bagi anak-anak dan melemparkannya kepada anjing. Hal yang dimaksud Yesus adalah Yesus harus mengusahakan dahulu keselamatan 
orang Israel atau orang Yahudi, yang telah menjadi "anak" Allah dan ahliwaris janjijanji, sebelum dapat mengusahakan keselamatan orang kafir yang di dalam pandangan orang Yahudi hanya "anjing". Oleh karena itu Yesus lebih dulu mengutamakan orang Israel kemudian orang yang bukan Israel, sebab Yesus datang untuk semua orang.

\section{Perempuan Membenarkan (Menerima) Perkataan Yesus (ay. 27)}

Ketika Yesus mengatakan bahwa tidak patut mengambil roti yang disediakan untuk anak-anak dan melemparkannya kepada anjing, perempuan itu merespon perkataan Yesus dengan mengatakan: "Benar Tuhan, namun anjing itu makan remah-

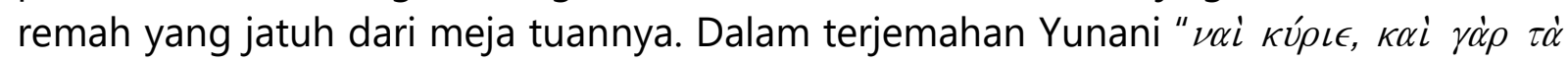

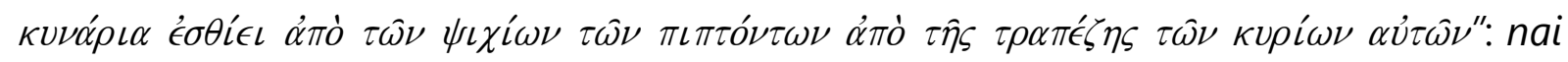
kyrie kai gar ta kynaria esthiei apo ton psichion ton piptonton apo tes trapezes ton kyrion auton. Dalam terjemahan Lama "Benarlah, ya Tuhan, tetapi anjing itu pun makan segala remah-remah, yang jatuh dari atas meja tuannya". Terjemahan Indonesia Literal Translation "Benar, Tuhan, karena anjing itu pun makan dari remahremah yang jatuh dari meja tuannya". Terjemahan Firman Allah Yang Hidup "Benar, sahut wanita itu, tetapi anak-anak anjing pun dibolehkan memakan remah-remah yang terjatuh dari meja". Dan terjemahan King James Version "Truth, Lord: yet the dogs eat of the chumbs which fall from their masters's table". Dari semua terjemahan tersebut yang sesuai adalah terjemahan Indonesia Literal Translation.

Kata "Benar" dalam Kamus Besar Bahasa Indonesia ada beberapa arti: (i). Sesuai sebagaimana adanya (seharusnya); betul, tidak salah. (ii). Adil; (iii). Dapat dipercaya (cocok dengan keadaan yang sesungguhnya); tidak bohong" (Depdiknas, 2001, s.v. "benar"). Kata benar dalam bahasa aslinya $\nu \alpha \iota$ (Bibleworks 7, s.v. " $\nu \alpha \iota ")$. Jika kembali ke nas kata Benar adalah sesuatu yang tidak bohong atau tidak salah. Jadi perempuan Kanaan itu membenarkan perkataan Yesus tersebut yang mengatakan bahwa dia adalah anjing. Perempuan ini membenarkan bahwa dia adalah orang yang berdosa, namun dia tidak pernah menyerah begitu saja, malah sebaliknya Perempuan ini mengakui dirinya yang seharusnya tidak pantas menerima mujizat kepada Yesus.

Dan juga selain perempuan ini membenarkan apa yang Yesus katakan pada dirinya, kata remah-remah di sini juga menunjukkan bahwa perempuan itu percaya, remahpun dari Yesus cukup untuk dia. Jadi, dia memiliki pandangan terhadap Yesus lebih tinggi daripada murid-murid. Dia tahu bahwa sedikit saja dari Yesus, itu sudah cukup baginya. Jadi, itu menunjukkan iman dan kepercayaan perempuan Kanaan itu kepada Yesus.

\section{Respons Yesus Kepada Perempuan Kanaan (ay. 28)}

\section{Yesus Memuji Iman Perempuan Kanaan (ay. 28a)}

Setelah perempuan ini mengatakan yang sebenarnya kepada Yesus dan dia mengakui bahwa dirinya berdosa dan tidak layak menerima mujizat dari Yesus dan 
berbagai hal harus diterima dan dilewati oleh perempuan Kanaan ini, Yesus pun memuji Iman yang dimiliki oleh perempuan Kanaan ini. Dalam mencapai hal seperti ini, perempuan Kanaan harus menjalani hal yang tidak menyenangkan baginya, contoh seperti awalnya dia tidak dijawab oleh Yesus setiap seruannya (ay 22), dan dia harus diusir dari tempat itu karena telah berteriak-teriak mengikuti Yesus dan muridmurid-Nya (ay 23), bahkan sampai ditolak dan tidak dianggap tidak layak menerima mujizat atau pertolongan dari Yesus (ay 24), dan perempuan Kanaan ini bahkan dibilang anjing (ay 26). Itu semua hal yang harus dilewati oleh perempuan Kanaan ini.

Kata "Memuji" dalam Kamus Besar Bahasa Indonesia ada 2 arti, yaitu: (i). Melahirkan kekaguman dan pengharapan kepada sesuatu (yang dianggap baik, indah, gagah berani, dsb); (ii). Memuliakan (nama Tuhan dsb; Depdiknas, 2001, s.v. "memuji")." Dalam kata asli $\epsilon \pi \alpha \iota \nu 0 \sigma$ (Newman Jr., 1991, p. 60) noun nominatif tunggal maskulin. Yang menunjukkan Yesus memuji perempuan Kanaan ini dengan melihat iman yang dimiliki olehnya. Jika kembali ke nas, memuji yaitu kita mengatakan sesuatu yang baik dan layak untuk menerima atau menggunakannya. Jadi Yesus memuji Iman yang dimiliki oleh perempuan Kanaan ini, yang membuat dia tidak pernah menyerah ketika menginginkan sesuatu dengan kesungguhan hatinya.

Itulah yang Yesus inginkan kepada orang-orang yang percaya, yaitu memiliki Iman yang teguh di dalam Tuhan, tidak mudah menyerah ketika sedang menghadapi hal yang membuat dirinya jatuh dan tidak memiliki pengharapan kepada Yesus, serta memiliki keyakinan dan kepercayaan yang sungguh kepada Yesus.

\section{Yesus Mengabulkan Permintaan Perempuan Kanaan (ay. 28b)}

Selain Yesus memuji iman dari perempuan Kanaan ini, Yesus pun mengabulkan permintaan perempuan Kanaan ini, yang di mana perempuan ini tidak menyerah begitu saja ketika sedang mengalami persoalan yang begitu hebat dia rasakan.

Kata "Mengabulkan" dalam Kamus Besar Bahasa Indonesia adalah meluluskan (permintaan, doa, dan sebagainya); mengiakan" (Depdiknas, 2001, s.v. "mengabulkan"). Namun sebelum mengabulkan Permintaan perempuan Kanaan itu, Yesus mendengarkan seruan yang tulus dari hati Perempuan ini, kata mendengarkan

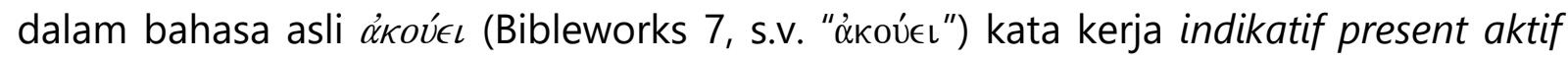
orang ketiga tunggal, yang menunjukkan suatu tindakan yang pasti dan sedang dilakukan, seperti yang Yesus lakukan kepada perempuan Kanaan ini. Pada akhirnya Yesus pun mengabulkan permintaan dari perempuan Kanaan ini. "Dari perempuan Kanaan ini, sebagai orang yang percaya kita mendapat pelajaran tentang iman dan kasih. Karena sangat mengasihi anaknya, ia berani menerobos sekat-sekat dan menyeberangi tapal-tapal batas. Kasihnya yang besar itu membuatnya beriman kepada Yesus. Seperti ditulis Paulus, kasih perempuan Kanaan kepada putrinya telah memampukannya untuk menutupi segala sesuatu, termasuk hinaan dan cercaan, untuk percaya segala sesuatu dan mengharapkan segala sesuatu kepada Yesus, dan sabar menanggung segala sesuatu agar bisa memperoleh penyembuhan serta kebebasan bagi anak perempuannya" (1 Kor 13:7; Kristanto, 2009, p. 45). Jadi jangan 
pernah menyerah ketika mengalami persoalan dalam kehidupan, karena Yesus akan selalu ada bersama dengan orang percaya.

Dengan demikian, pengertian di atas bahwa sikap yang perlu dimiliki oleh setiap orang percaya adalah beriman dan percaya dengan kesungguhan hati kepada Yesus. Karena tidak ada kekuatan di dalam iman, kecuali iman itu menuju kepada satu pribadi yaitu Yesus Kristus. Iman perempuan itu kuat karena dia percaya bahwa Yesus sudah luar biasa. Sehingga Yesus pada akhirnya mengabulkan permintaan perempuan Kanaan itu.

\section{Implikasi Iman Perempuan Kanaan Bagi Kehidupan Orang Percaya Masa Kini}

\section{Iman Yang Sejati Hanya Bergantung Pada Belas Kasihan Yesus}

Dapat dilihat bersama bahwa Iman yang sejati adalah iman yang hanya bergantung kepada belas kasihan Yesus. Seperti yang perempuan Kanaan ini lakukan bahwa dia meminta belas kasihan kepada Yesus hanya untuk kesembuhan anaknya yang sedang mengalami kerasukan setan. Itu adalah salah satu bukti bahwa perempuan Kanaan ini sangat bersungguh-sungguh meminta belas kasihan kepada Yesus dan dia hanya bergantung kepada Yesus saja (ay. 22). Dari hal ini, apa yang telah perempuan Kanaan itu lakukan dengan cara dia bergantung hanya kepada Yesus untuk meminta belas kasihan-Nya. Tindakan yang perempuan Kanaan ini lakukan membantu dia lebih dekat lagi kepada Yesus dan terus berharap kepada Yesus.

Menurut Matius, orang yang menyerukan belas kasihan, harus berlaku dengan penuh belas kasihan terhadap sesama. Belas kasihan adalah kewajiban setiap pengikut Yesus dan menjadi ciri khas agama Kristen (Leks, 2003, p. 404). Seperti yang telah perempuan Kanaan ini lakukan dia bersungguh-sungguh dengan segenap hatinya meminta belas kasihan kepada Yesus, dan itu adalah salah satu perbuatan yang benar yang harus dilakukan juga oleh orang Percaya. Selain itu Yesus juga mengatakan pada pasal sebelumnya, yaitu: "Yang Kukehendaki ialah belas kasihan dan bukan persembahan, karena Aku datang bukan untuk memanggil orang benar, melainkan orang berdosa" (Mat. 9:13). Jadi dari ayat tersebut Yesus sangat menegaskan bahwa yang dikehendaki-Nya ialah belas kasihan bukan persembahan. Ketika seseorang ingin mendapatkan belas kasihan kepada orang lain, dia juga harus terlebih dahulu memiliki hati belas kasihan itu seperti yang dilakukan oleh perempuan dan Yesus ini.

Dalam Matius 17:15 juga membahas tentang seseorang yang datang kepada Yesus untuk meminta dikasihani untuk kesembuhan anaknya yang sakit ayan dan sangat menderita, orang itu sangat bersungguh-sungguh datang kepada Yesus untuk meminta belas kasihan-Nya. Dia memiliki iman yang sangat kuat untuk kesembuhan anaknya tersebut, seperti yang dilakukan oleh perempuan Kanaan itu, dengan dia memiliki iman yang sejati dia bersungguh-sungguh meminta belas kasihan kepada 
Yesus, dan pada akhirnya Yesus pun menjawab seruan yang perempuan Kanaan itu sampaikan yaitu kesembuhan anaknya.

Selain itu, tindakan yang dilakukan oleh perempuan Kanaan itu juga sebagai bagian dari kepercayaannya kepada Yesus. Dia percaya kepada Yesus dan dia yakin bahwa Yesus akan menyembuhkan anaknya yang menderita kerasukan, untuk itu dia meyakinkan itu dengan kesungguhan hati dan imannya kepada Yesus. Melalui sikap dan perbuatan yang dilakukan oleh perempuan Kanaan ini, perempuan Kanaan ini menunjukkan imannya, dan melalui tindakan yang perempuan Kanaan ini lakukan juga dia memperoleh sesuatu yang dia inginkan yaitu kesembuhan anaknya.

Yakobus menuliskan jika iman tanpa adanya perbuatan adalah mati (Yak. 2:26). Iman tanpa adanya tindakan atau perbuatan itu adalah perwujudan dari apa yang diimaninya dan merupakan kesia-siaan. Jadi, orang-orang yang mengaku percaya dan memiliki iman namun tidak dibarengi dengan perbuatan atau tindakan, maka itu adalah iman yang mati. Demikian hal yang dilakukan oleh perempuan Kanaan ini, yaitu dia mengimani dengan melakukan tindakan yaitu meminta pertolongan dengan sungguh-sungguh tanpa adanya keterpaksaan, lewat itu Yesus pada akhirnya memiliki belas kasihan kepada dirinya dan menjawab seruan dari Perempuan Kanaan ini. Demikian halnya orang-orang percaya harus memiliki iman yang hidup.

Iman yang hidup dengan mengaku bahwa Yesus adalah Tuhan yang dapat melakukan perbuatan dan mujizat yang hebat yang mewujudkan imannya. Demikianlah, jika kita datang kepada Yesus dengan kesungguhan hati meminta pertolongan kepada-Nya tanpa memaksa kehendak kita, dan mengaku bahwa Yesus dapat melakukan perbuatan dan mujizat yang hebat, kita yakin bahwa semuanya akan diberikan kepada kita. Iman yang benar dengan perbuatan akan memperoleh keselamatan, dan Iman yang berpusat hanya kepada Yesus.

\section{Iman Yang Benar Adalah Iman Yang Tidak Mudah Menyerah}

Pada Matius 15:23a di situ dikatakan bahwa Yesus sama sekali tidak menjawab seruan dari perempuan Kanaan ini, bahkan sampai disuruh untuk pergi dari situ oleh murid-murid-Nya. Namun, dapat diperhatikan bahwa perempuan Kanaan ini tidak mudah menyerah begitu meskipun tidak ada jawaban dari Yesus pada saat itu. Kalau orang-orang percaya melihat bersama bagaimana perjuangan Ibu dari anak yang mengalami kerasukan setan ini, demi menginginkan anaknya sembuh dia bermohon kepada Yesus untuk dapat menyembuhkan anaknya tersebut, tetapi harus ada hal yang diterima oleh ibu ini yaitu Yesus pada awalnya tidak menjawab setiap seruan yang disampaikan kepada Yesus, namun dia meyakini bahwa dia akan ditolong. Kemudian Yesus pun menjawab bahwa Dia diutus hanya kepada domba-domba yang yang hilang dari umat Israel (ay. 24). Mendengar kata-kata Yesus seperti itu, seharusnya perempuan Kanaan ini pergi dan meninggalkan Yesus, namun sebaliknya yaitu perempuan ini tetap bertahan dengan penuh keyakinannya. "Hal ini kedengarannya sebagai keputusan terakhir. Tetapi perempuan itu masih berharap 
kepada Yesus sebagai pengharapan terakhir, dan ia datang dan bertulut di hadapanNya" (Song, 2008, p. 199).

Melihat tindakan yang perempuan Kanaan ini lakukan dengan cara dia tidak mudah menyerah meskipun tidak dijawab oleh Yesus, dia tetap berusahan dan tidak berputus asa akan hal itu. Dalam kehidupan orang percaya masa kini, tidak banyak orang-orang dapat berbuat atau menjalankan seperti yang perempuan Kanaan ini lakukan, bisa saja ketika Yesus tidak menjawab doa orang-orang itu, orang itu akan pergi dan terus mengeluh kepada Yesus mengapa doa orang-orang atau seruan orang-orang itu tidak dijawab oleh Yesus, namun sebagai orang yang percaya kembali melihat sikap yang dilakukan oleh perempuan Kanaan ini yaitu tetap bertahan dan tidak mudah menyerah meskipun tidak dijawab oleh Yesus, dan sebagai orang percaya juga harus memiliki iman yang teguh ditengah goncangan yang terjadi didalam kehidupan setiap orang.

Melalui sikap dan tindakan dari perempuan Kanaan ini sebagai orang yang percaya dapat belajar bagaimana harus tetap bertahan ketika seruan setiap orang tidak Yesus jawab, namun sebagai orang yang percaya harus terus meyakini bahwa Yesus akan memberikan pertolongan kepada setiap orang. Dan semua apa yang telah terjadi kepada perempuan Kanaan itu akan terjadi pula kepada setiap orang percaya. Intinya yaitu sebagai orang yang percaya harus memiliki iman yang teguh, yang tidak berputus asa dan tidak mudah menyerah ketika ditolak, namun tetap bertahan dengan penuh keyakinan itu adalah bentuk iman yang sejati.

\section{Tetap Bersabar Menunggu Waktu Tuhan}

Kebanyakan orang-orang sekarang tidak sabar ketika menunggu jawaban dari Tuhan. Ketika Yesus mengatakan bahwa: "Tidak patut mengambil roti yang disediakan bagi anak-anak dan melemparkannya kepada anjing (ay. 27)", "ucapan itu mempertahankan martabat bangsa Israel sebagai umat Allah" (Bolkestein, 2004, p. 138). Dan juga anak-anak disini (orang Yahudi) yang lebih diutamakan dari pada anjing (orang bukan Yahudi). Jadi orang Yahudi lebih diutamakan daripada orang yang bukan Yahudi (perempuan Kanaan), dan sebagai orang yang memiliki iman yang benar yaitu dia harus mengutamakan tujuan utama Allah bagi umat-Nya. Dan ayat selanjutnya mengatakan bahwa perempuan Kanaan ini membenarkan apa yang Yesus katakan kepada dirinya yaitu: "Benar Tuhan, namun anjing itu makan remahremah yang jatuh dari meja tuannya. Perkataan yang tidak akan pernah dijawab siapapun ketika dikatakan sebagai anjing, namun perempuan Kanaan ini tidak malu untuk mengungkapkan bahwa dirinya adalah orang yang berdosa yang tidak selayaknya menerima mujizat dari Tuhan dan dia menerima apa yang Yesus katakan kepadanya.

Lewat sikap perempuan Kanaan ini sebagai orang yang percaya dapat melihat bahwa dia mengutamakan apa yang seharusnya diutamakan oleh Yesus pada saat itu dan tetap bersabar menunggu jawaban dari Tuhan. Dia tidak memaksa Yesus untuk cepat-cepat menolongnya atau memberikan mujizat kepada dia dan anaknya, namun 
dia menunggu dan bersabar bahwa Yesus akan melakukan hal yang dia harapkan tersebut di dalam kehidupannya. Ketika perempuan ini membenarkan apa yang Yesus katakan kepadanya, dia meresponsnya dengan sangat baik: "Ya, anak-anak kecil harus diberi makan. Tidak ada yang meragukannya, namun anjing kecilnya juga masih bisa mendapatkan remah-remah yang jatuh. Orang Yahudi memiliki Engkau sepenuhnya, mereka memiliki kehadiran-Mu, mereka memiliki firman-Mu, mereka duduk dikaki-Mu, mereka pasti tidak akan iri dengan permintaanku" (Mathews, 2013, p. 92). Itu adalah perkataan dari perempuan Kanaan itu, di mana dia mengutamakan apa yang menjadi tujuan utama Allah untuk umat-Nya terlebih dahulu, kemudian pada akhirnya dia akan memperoleh apa yang dia inginkan dalam kehidupannya.

Sebagai orang-orang yang percaya, sikap dari perempuan Kanaan ini adalah salah satu contoh perbuatan yang baik dan patut untuk diikuti, yang dimana dia lebih mengutamakan untuk Allah lebih dulu menolong umat-Nya Israel, yang di mana lebih penting itulah yang diutamakan, dan tetap meyakini dengan iman bahwa Yesus akan menolong setiap orang percaya tepat pada waktu-Nya, sebab waktu Tuhanlah yang terbaik dan Yesus datang untuk semua orang bukan hanya untuk orang tertentu saja. Jadi, bersabar dalam menanti jawaban Tuhan itulah yang harus dipegang oleh orang-orang percaya masa kini.

\section{Tetap Mempertahankan Iman Percaya Kepada Tuhan}

"Yesus lebih dulu tidak bersedia untuk menyembuhkan anak dari perempuan Kanaan, yaitu wanita bukan-Yahudi, tetapi melalui iman besar yang percaya kepada Yesus, ia juga dapat menerima keselamatan dari Yesus, Sang Mesias Israel" (Drewes, 1982, p. 249). "Mulai dari perempuan Kanaan ini datang memohon kepada Tuhan Yesus untuk menyembuhkan anaknya, tetapi Yesus tidak memperdulikannya, bahkan murid-murid Yesus mengusir dia, tetapi dia tetap memohon kepada Yesus untuk menolongnya. Yesus bahkan mengeluarkan kata-kata pedas yang menyakitkan, namun perempuan ini tetap memilih untuk merendahkan dirinya dan berharap pada Yesus" (Ellesse, 2007, p. 51). Sebagai orang yang percaya dapat dilihat bagaimana perjalanan pengorbanan yang dilakukan oleh perempuan Kanaan ini untuk kesembuhan anaknya yang menderita kerasukan, sungguh besar keyakinannya kepada Yesus pada saat itu.

Beriman dan percaya kepada Yesus sangatlah patut untuk orang percaya lakukan di dalam kehidupan orang percaya, dengan iman yang sungguh-sungguh kepada Yesus segala sesuatu yang setiap orang inginkan akan terjadi di dalam kehidupannya, namun segala sesuatu itu harus dibarengi dengan perbuatan. Tanpa adanya perbuatan juga sebagai orang yang percaya tidak dapat memperoleh yang diharapkan. Seperti yang perempuan Kanaan ini lakukan, meskipun dia harus menerima sesuatu yang tidak pernah dia pikirkan sebelumnya, namun dia tidak pernah menyerah akan hal itu dia malah semakin bersemangat dan bersungguhsungguh kepada Yesus bahwa Yesus akan menyembuhkan anaknya yang sedang menderita karena kerasukan setan. 
Upah adalah pahala, pahala yang akan didapatkan oleh perempuan Kanaan dari apa yang telah dia lakukan sebelumnya, sesuatu yang dia kerjakan untuk sebuah hasil yang dia ingin dapatkan, yaitu kesembuhan anaknya. Perjalanan yang sangat begitu mengharuskan orang-orang beriman melakukan sama seperti apa yang dilakukan oleh perempuan Kanaan ini. Mulai dari datang meminta belas kasihan kepada Yesus, tetap merendahkan hati ketika tidak dijawab dan ditolak oleh Yesus dan muridmurid-Nya, tetap bertahan ketika orang lain yang lebih diutamakan daripada diri setiap orang percaya, dan pada akhirnya setiap orang akan mendapatkan upah dari apa yang di lakukan dengan kesungguhan hati.

Jadi, dari semua hal yang perempuan Kanaan ini lakukan bagi anaknya, sebagai orang-orang percaya harus memiliki iman seperti perempuan ini, iman yang tidak pernah putus asa, iman yang tidak pernah menyerah ketika ditolak dan iman yang tetap bertahan ketika diuji. Dan pada akhirnya setiap orang akan memperoleh upah yang seharusnya didapatkan dari apa yang telah dikerjakan sebagai orang-orang yang percaya kepada Yesus, dan upah itu adalah tetap mempertahankan iman percaya kepada Tuhan untuk sebuah hasil yang diharapkan.

\section{KESIMPULAN}

Dari hasil uraian yang dilakukan oleh penulis terhadap Injil Matius 15:21-28, mengenai iman perempuan Kanaan dan implikasinya bagi kehidupan orang percaya masa kini, maka penulis menarik beberapa kesimpulan sebagai berikut:

Pertama, iman yang sejati hanya bergantung pada belas kasihan Yesus. Seperti yang diceritakan di dalam kitab Matius 15:21-28 tentang seorang perempuan Kanaan yang memintra pertolongan kepada Tuhan. Iman yang sungguh-sungguh kepada Yesus adalah iman yang hanya bergantung pada belas kasihan dari Yesus, bukan bergantung dari hal-hal yang lainnya yang dapat mendahului dari belas kasihan Yesus. Sebagai orang percaya harus bergantung kepada belas kasihan Yesus, karena lewat belas kasihan itu setiap orang akan mendapatkan apa yang di harapkan dari Yesus, dan setiap orang yakini itu bahwa Yesus akan memberikannya pertolongan didalam kehidupan setiap orang percaya.

Kedua, iman yang benar adalah iman yang tidak mudah menyerah. Ketika tidak diterima atau ditolak, sebagai orang percaya harus tetap bertahan apapun persoalan yang akan terjadi pada kehidupan orang-orang, itulah adalah salah satu upaya agar setiap orang-orang mendapatkan apa yang diharapkan. Sebagai orang percaya harus terus berjuang untuk tetap bertahan meskipun harus menghadapi persoalan yang kadang tidak diketahui akan terjadi dalam kehidupan setiap orang percaya. Untuk itu sebagai orang yang percaya kepada Yesus harus memiliki Iman yang tidak mudah menyerah.

Ketiga, tetap bersabar menunggu waktu Tuhan. Seperti yang dilakukan oleh perempuan Kanaan ini, di mana dia mengutamakan terlebih dahulu apa yang akan dilakukan oleh Yesus, dan kemudian dia akan menerima apa yang dia harapkan dari 
Yesus. Jadi, iman yang benar itu adalah tetap bersabar menunggu waktu Tuhan dan lebih mengutamakan apa yang menjadi tujuan Allah bagi umat-Nya, bukan mengutamakan apa yang menjadi harapan atau keinginan setiap pribadi orang, karena pada akhirnya tujuan Allah lah yang akan terjadi dalam kehidupan setiap orang. Jadi, sebagai orang yang percaya harus tahu apa yang menjadi tujuan utama Allah atas umat-Nya, jangan mendahului semuanya dari kehendak-Nya Tuhan, dan tetap bersabar menunggu waktu-Nya Tuhan, karena itulah yang terbaik di dalam kehidupan setiap orang.

Keempat, tetap mempertahankan iman percaya kepada Tuhan. Seperti yang dilakukan perempuan Kanaan ini, yang di mana dia mendapatkan hasil dari apa yang telah dia lakukan, meskipun dia harus melewati berbagai banyak hal. Namun dia tidak pernah menyerah. Ketika orang-orang telah mengerjakan semua yang telah di lakukan, setiap orang pasti akan mendapatkan upah dari itu semua, karena segala sesuatu yang telah di kerjakan dengan kesungguhan hati, setiap orang-orang yang percaya layak untuk mendapatkan pahala dari apa yang telah di lakukan, dan itu semua dapat terjadi karena dia tetap mempertahankan Iman percayanya kepada Tuhan, dan dia meyakini bahwa Tuhan akan menolong anaknya.

\section{KEPUSTAKAAN}

(2015). Alkitab Terjemahan Baru. Jakarta: Lembaga Alkitab Indonesia.

Barclay, William. (1991). Pemahaman Alkitab Setiap Hari Injil Matius. Jakarta: BPK Gunung Mulia.

Bavinck, J. H. (2004). Sejarah Kerajaan Allah 2: Perjanjian Baru. Jakarta: BPK Gunung Mulia.

Berends, Bill. (2010). Teologia Dasar. Jakarta: Suara Harapan Bangsa.

Bible Works 7.

Bolkestein, Marinus Hendrik. (2004). Kerajaan Yang Terselubung. Jakarta: BPK Gunung Mulia.

Conner, Kevin J. (2004). Interpreting The Scriptures Hermeneutik, Sebuah Buku Teks Tentang Cara Menafsirkan Alkitab. Malang: Gandum Mas.

Drane, John. (2005). Memahami Perjanjian Baru. Jakarta: BPK Gunung Mulia. . (1996). Memahami Perjanjian Baru: Pengantar Historis - Teologis. Jakarta: BPK Gunung Mulia.

Drewes, B. F. (1982). Satu Injil Tiga Pekabar. Jakarta: BPK Gunung Mulia.

Ellesse, Nindy. (2007). Hidup Bukan Teka-teki. Jakarta Selatan: VisiMedia.

Fee, Gordon D., dan Douglas Stuart. (1989). Hermeneutik Bagaimana Menafsirkan Firman Tuhan Dengan Tepat. Malang: Gandum Mas.

Hadiwardoyo, Al Purwa. (2010). Catatan-Catatan Singkat Tentang Kitab Suci. Yogyakarta: Kanisius.

Hartono, Andry. (2006). Sembuh Karena Iman, Harapan dan Kasih. Yogyakarta: Kanisius. 
Hayes, John H dan Carl R. Holladay. (2006). Pedoman Penafsiran Alkitab. Jakarta: BPK Gunung Mulia.

Heer, J. J. de. (1982). Tafsiran Alkitab Injil Matius Ps 1-22. Jakarta: BPK Gunung Mulia. Henry, Matthew. (2008). Tafsiran Injil Matius 15-18. Surabaya: Momentum.

Hubbard, W. S., D. A. Lasor, dan F. W. Bush. (1993). Pengantar Perjanjian Lama 1:

Taurat dan Sejarah. Jakarta: BPK Gunung Mulia.

Depdiknas. (2001). Kamus Besar Bahasa Indonesia. Jakarta: Balai Pustaka.

Kingsbury, Jack Dean. (2004). Injil Matius Sebagai Cerita. Jakarta: BPK Gunung Mulia.

Kristanto, Purnawan. (2009). My Blessed Family Inspirasi Menuju Keluarga Bahagia \& Diberkati. Jakarta: BPK Gunung Mulia.

Leks, Stefan. (2003). Tafsir Injil Matius. Yogyakarta: Kanisius.

Marxsen, Willi. (2008). Pengantar Perjanjian Baru. Jakarta: BPK Gunung Mulia.

Mathews, Alice. (2013). Wanita Yang Dibimbing Yesus: Teladan Bijak dari Para Wanita

Perjanjian Baru. Jakarta: Duta Harapan Dunia.

Morris, Leon. (2016). Injil Matius. Surabaya: Momentum.

Mounce, William D. (2011). Basics of Biblical Greek. Malang: Literatur SAAT.

Newman, Barclay M., Philip C. Stine, P. G. Katoppo. (2019). Pedoman Penafsiran Alkitab: Injil Matius. Jakarta: Lembaga Alkitab Indonesia.

Newman Jr., Barclay M. (1991). Kamus Yunani-Indonesia untuk Perjanjian Baru. Jakarta: BPK Gunung Mulia.

Pasaribu, Marulak. (2005). Eksposisi Injil Sinoptik: Mengenal Yesus yang Diberitakan dalam Injil Matius, Markus, dan Lukas. Malang: Gandum Mas.

Pfeiffer, Charles F., dan Everett F. Harison. (2013). The Wycliffe Bible Commentary Volume 3. Malang: Gandum Mas.

Rouw, Randy Frank. (2017). Kepercayaan Rahab Berdasarkan Yosua 2:1-24. Jurnal Jaffray, 15(2), 201-230. https://ojs.sttjaffray.ac.id/JJV71/article/view/259.

Santoso, David Iman. (2009). Theologi Matius: Intisari dan Aplikasinya. Malang: Literatur SAAT.

Sitompul, A. A. dan Ulrich Beyer. (2008). Metode Penafsiran Alkitab. Jakarta: BPK Gunung Mulia.

Sitorus, Jonter Pandapotan. (2019). Wawasan Dunia Kristen dan Dunia Ilmu Pengetahuan terhadap Bahasa (Edisi Revisi). Malang: Evernity Fisher Media.

Song, Choan-seng. (2008). Allah Yang Turut Menderita. Jakarta: BPK Gunung Mulia.

Sosipater, Karel. (2010). Etika Perjanjian Baru. Jakarta: Suara Harapan Bangsa.

Stamps, Donald C. Ed. (2015). Alkitab Penuntun Hidup Berkelimpahan. Malang: Gandum Mas.

Suawa, Ferdinan K. (2009). Memahami Gramatika Dasar Bahasa Yunani Koine. Bandung: Kalam Hidup.

Sutanto, Hasan. (1991). Hermeneutik: Prinsip dan Metode Penafsiran Alkitab. Malang: SAAT.

. (2003). Perjanjian Baru Interlinear Yunani-Indonesia dan Konkordansi Perjanjian Baru (PBIK) Jilid II. Jakarta: Lembaga Alkitab Indonesia. 
Tenney, Merril C. (2017). Survei Perjanjian Baru. Malang: Gandum Mas.

Verkuyl, J. (2001). Aku Percaya. Jakarta: BPK Gunung Mulia, 2001.

Wismoady, Wahono S. (2009). Di Sini Kutemukan: Petunjuk Mempelajari dan Mengajarkan Alkitab. Jakarta: BPK Gunung Mulia. 